Ключевые слова: студенты инженерно-технических специиальностей, учебный блог, профессиональная иноязычная компетентность, дистанционное обучение.

SLABKO V. N., ZAPOLSKA YU. A. Educational blogs as instrument of the controlled from distance form of teaching in forming of professional for eign competence of students of technical specialities.

One of the most thorny and sharp pedagogical problems of foreign preparation of students of technical establishments of higher education on the whole is providing of individualization of studies and stimulation of motivation of students to self to development. In opinion of author of the article, the possible effective mean of decision of these problems in the controlled from distance form of teaching is the use of technology of conduct of educational blogs. Authorial methodology of conduct of blog is partly alike with a project method and method of "portfolio". From one side, an educational blog it is expedient to examine as a project: his creation and regular filling require a pragmatic orientation on a result, which can be comprehended, apply in the real practical activity. In a conduct a blog the same as and in the method of projects, students are attracted in the dialog of cultures and have the opportunity to get a feed-back from professional linguists and носителей of foreign language on the basis of function of comments, built into a blog-platform. On the other hand, an educational blog carries out the role of electronic "portfolio" are controls and estimation of quality of independent work of student and his progress in forming of professional foreign competence, that appear by comparison to the first and last record in a blog. A blog is and by the specific report of student in which the presented results of analysis of English-language materials on professional subjects. At the same time availability of blog in a network the Internet can help employers to estimate ability of graduating student to decide professional tasks which require knowledge of foreign language.

Technology of forming of professional foreign competence of students of technical specialities in the controlled from distance teaching on the basis of educational blogs provides for : presence of feedback with students as a system of instantaneous reports, e-mail and other facilities which allow operatively to decide nascent questions; use of the professionally orientated educational materials, actual for corresponding direction of preparation; an account of professional interests and further professional plans of students is in the controlled from distance teaching.

Keywords: students of technical specialities, educational blog, professional foreign competence, controlled from distance teaching.

DOI: https://doi.org/10.31392/NZ-npu-145.2019.22

УДК 371.134:615.15:37.048,4

Філіппова Л. В.

\title{
ПРОФЕСІЙНА РЕФЛЕКСІЯ ВИКЛАДАЧА У ВИЩИХ НАВЧАЛЬНИХ ЗАКЛАДАХ
}

В статті розглядаються підходи професійної рефлексї̈ викладачів, як самопізнання, самоаналіз. Описується поетапний проиес самоаналізу під час педагогічного процесу та поетапний процес самооцінки, які впливають на професійно-особистісне самовдосконалення викладача. Всі головні етапи дозволяють викладачу розпізнати та пізнати внутрішні процеси, які відбуваються під час педагогічної діяльності. 3 педагогічного рівня рефлексії розкривається намагання викладача не лише передати науково-практичну інформачію студентові, a $i$ намагання викладача до саморозвитку рефлексівних власних дій. Розглядається вплив 
рефлексивної діяльності на пізнання власної індивідуальності. Висвітлюються чотири основні функції, які притаманні педагогічній діяльності. Спостерігаючи студент за викладачем, котрий під час практичний занять миттєво використовуючи основні функції, надає яскравий приклад як можна оволодіти рефлексивними діями. Розглядається партнерська взаємодія викладача та студента за допомогою трьох складових частин. Саме перша сторона педагогічної діяльності займає важливе місие під час педагогічного процесу. Лише викладач може викликати мотивацію у студента для вивчення та подальшого саморозвитку свойми діями, використовуючи певні інструменти професійного іміджу. Наводиться опис всіх компонентів, якими користується викладач під час проведення практичних або лекиійних заняття. Відбувається детальний аналіз всіх компонентів педагогічної рефлексії, які виникають під час обміну між викладачем та студентом в педагогічній діяльності викладача. В статті описується намагання викладача навчити студента критично мислити на власних діях.

Ключова слова: самопізнання, самоаналіз, иільовий компонент,змістовний компонент, діяльнісний компонент, результативно-оцінюючий компонент.

В університетах потрібно формувати людину як активну особистість, суб'єкта діяльності. Для цього потрібно викладачу поставити ціль не лише передавати студентові певний об'єм знань, вмінь та навичок, а також намагатися розвинути його здібності, самовизначитися в творчих відносинах, самостійно навчитися вирішувати різного рівня задачі, приймати рішення в нестандартних умовах. Щоб це досягнути потрібно вміти піддавати власні дії до рефлексії. Викладач повинен навчити студента до рефлексійних дії, внаслідок цього викладач повинен сам володіти вміннями до рефлексії.

Поняття рефрлексія у вищій школі та види педагогічної рефрлексії описувалися авторами $[1,2]$ згадувалося Літературний пошук показав, якщо розглядати професіональну рефлексію як самопізнання, самоаналіз особистості то можна виділити особистісну рефрлексію. Ця рефрлексія надає можливість викладачу вміння контролювати себе, керувати власними емоціями та настрієм. Особистісна рефрлексія - це $є$ перебудова власного розуму, діяльності. А. В. Хуторський [3] та І. А. Стеценко [4] в працях описують, що саме викладач має готові засоби для організації процесу засвоєння знань на кожному етапі, він здатний використовувати та застосовувати будь-які готові механізми для засвоєння, але не можливо засвоїти нові знання без самоаналізу знань, які були отримані раніше в процесі навчання.

Тобто рефрлексивна діяльність дозволяє пізнати свою індивідуальність. Завдяки рефрлексії можна не лише осмислювати власну діяльність, але i планувати, будувати структурну основу, яка прямо витікає із минулої діяльності.

Особистісна рефрлексія викладача пов'язана, як ми спостерігаємо, 3 самопізнанням, самоаналізом, самоорганізацією до осмислення та переосмисленням власних вчинків, поведінки. Самопізнання дозволяє викладачу розпізнати та пізнати внутрішні процеси, які відбуваються в середині людини. Викладач тоді здатний привести свою дію до власних потреб та можливостей. За допомогою таких якостей контролю та корекції відбувається саморозвиток та самоудосконалення, які в конче потрібні викладачу вищих навчальних медичних та фармацевтичних закладів. Самооцінка $є$ основою самопізнання. Це не що інше, як метод самоконтролю. Він ґрунтується на систематичному аналізі своєї профресійної діяльності. 
Мета статті. Професійний розвиток викладача не можливий без педагогічної рефлексії, без розвитку самоаналізу. Потрібно враховувати механізми такої ресрлексії Н. Нікітіна, А. Железнякова, М. Петухов [5] виокремлюють два підходи до організації самоаналізу викладача:

Самоаналіз, який відбувається під дією порівняння своїх результатів 3 певним еталоном відповідної діяльності;

1) Самоаналіз, який відбувається під дією порівняння своїх результатів діяльності з попередніми результатами, де викладач простежує зміни та певну динаміку свого профресійного розвитку.

2) Саме такі підходи на нашу думку, дуже надихають викладача до професійно-особистісного самовдосконалення.

Процес самоаналізу та самооцінки обов'язково повинен відбуватися поетапно, як показав літературний пошук [5]:

- змістовий етап, який надає основу для спрямованої дії самоаналізу;

- процес взаємоаналізу та взаємооцінки власних результатів та чужої діяльності;

- процес індивідуального самоаналізу та самооцінки власним діям.

Стосовно самооцінки діяльності можна виокремити:

а) прогностичну самооцінку. Вона ґрунтується на попередньому аналізі власних можливостей;

б) процесуальна самооцінка. Вона ґрунтується на самоконтролі власних дій;

в) ретроспективна використовується на завершальному етапі діяльності.

Щоб навчити студентів викладач повинен бути спроможним керувати собою та всіма внутрішніми компонентами професійно-педагогічної діяльності.

Таким чином, рефрлексія $є$ процесом самоаналізу суб'єкту власної свідомості. Педагогічну рефлексію можна розглядати як:

- домінанту педагогічного процесу;

- головний чинник педагогічного процесу, який буде направлений на саморозвиток як викладача так і студента.

Викладач поступово змінюється під час педагогічного процесу, відбувається зміни в динаміці стану діяльності, мотивів діяльності, емоції та відчуття, знаній, вмінь. Розвиток відбувається в середині суб'єкту тому судити о процесі розвитку може лише сам викладач. Викладач надає самооцінку своєму розвитку, він само розмишляє, під час свої дії до самоаналізу, тобто все це відбувається через рефлексію. Таким чином педагогічна рефлексія це процес та результат фріксуємий викладачем, саме учасником педагогічного процесу, стан його розвитку, самовдосконалення.

Також може з'явитися питання чи обов'язково викладачеві мати здатність до рефрлексії під час навчального процесу. Так наприклад Г. А. Цукерман [6] стверджує, що навчити рефлексії не можливо, але допомогти навчатися можливо, а той хто вміє рефлексувати, той за звичай є поганим помічником.

А А. Б. Воронцов [7] наголошує, що викладач для розвитку у студентів рефрлексівних здібностей, повинен вміти рефрлексувати, тому що будь-яке викладання $є$ управлінською діяльністю. Ми вважаємо, що викладач повинен 
створити сприятливі умови для розвитку рефлексії у студентів. Для викладача повинен спрацьовувати принцип “вирощування", тобто викладач повинен створити умови для дій, для спілкування, комунікації які б супроводжували самозміни у студентів. Як ми розуміємо, що такій підхід потребує розвинутої рефлексивної здатності у самого викладача.

Потрібно пам'ятати, що при створенні цих умов викладач не повинен займати авторитарну позицію, а бути наставником або старшим братом для покращення навчального процесу.

Також не потрібно забувати і той момент, що в процесі рефлексії у викладача з'являються утруднення до своєї практичної діяльності. Цей момент можу бути обумовлений недостатнім рівнем рефлексії самого викладача, він може не розуміти та не бачити причин, які б заважали йому розуміти студента та впливати на нього.

В якості однієї із важливих педагогічних умов ефективної роботи $\epsilon$ педагогічний та методичний аналіз власної професійно-педагогічної діяльності. Саме ці два аналізи допомагають викладачеві подолати труднощі в своїй педагогічній діяльності.

Ми вважаємо, що найкращу педагогічну рефлексію будемо спостерігати в момент стимулювання студентів до самовизначення та в момент фрормування власного “Я”. В якості успішного розвитку педагогічної діяльності викладач вводить критерії “рефлексивної позиції” як інтегральний показник рівня осмислення, саме в цей момент, повинно відбуватися усвідомлення власної діяльності. Основними пунктами рефлексивного показника $є$ : цілеспрямованість, планування, аналіз та контроль за процесом діяльності, відчуття як мери та часу, вміння слухати і чути навколо студентів, критично мислити та прямувати до спілкування, а також бути готовим давати собі самооцінку на будь-якому моменті рефлексивної дії. Саме коли викладач надає собі самооцінку, він повинен стати в позицію, “спостерігача", "дослідника" або "контролера" по відношенню до своєї системи ціностних орієнтацій, до своєї діяльності; осмислити свій досвід, і все це заради того, щоб знову прийти до нового розуміння і до нових цінностних відношень.

На нашу думку, ця здатність $€$ динамічною формою, яка підкреслює профресіональну педагогічну діяльність. Вона підкреслює вміння реагувати на умови під час змін; реагувати на зміни, які відбуваються в середині особистості; переносити життєвий досвід із однієї ситуації до іншої. Завдяки динамічній формі виявляється стійкість, яка надає перевагу для розвитку, та переводить особу на високий рівень стійкості в умовах, що постійно змінюються педагогічної реальності.

Таким чином педагогічна рефлексія $\epsilon$ реальним феноменом або "механізмом", який здатний характеризувати здібності викладача, його виходи за звичайні рамки під час викладання свого предмету, до розширення власних рамок професійної ролі. Саме педагогічна рефлексія дозволяє викладу під час профресійної діяльності утримувати та контролювати свою поведінку.

Виходячи із вище описаного, ми можемо заключити, що викладач 
виражає себе та спрямовує свою діяльність виявляючи в неї свою активність . Викладач це людина, яка формує цілі діяльності, вибирає шляхи досягнення мети, а також аналізує та коректує одержані результати, а також коректує свої власні якості як суб'єкта діяльності, виявляє своє відношення до діяльності, до студентської діяльності, а це є не мала річ.

Під час своєї викладацької діяльності, ми використовуємо чотири основні функції. Освітня фрункція виражає направленість процесу до фрормування інтересу. Інтерес спонукає студента до нових знань, вмінь, навичок. Ця функція має теоретичні та практичні аспекти, інтеграція яких надає можливість з'єднати, як теорію та практику.

Розвиваюча фуннція - відображає вплив на розвиток мислення, як у студентів та і у викладачів. Особливе значення має розвиток уваги, сприйняття, мовлення. Всі ці аспекти надають можливість розвитку особистості.

Виховна функція - під час праці зі студентами відбувається фрормування ставлення студента до колективу, а колективу до студента. Також за допомогою цієї функції можлива сію секундна імпровізація і студент отримує інформацію за короткий час, яку не може отримати за будь-яким іншим методом. Саме за допомогою цієї функції студенти медичних закладів формують відношення до себе як до суб'єкту медичної діяльності, та розвивають якості комунікативності, працьовитості та інші.

Дослідницька функція - це вміння планувати, виокремлювати основні аспекти організації навчального процесу, наприклад:

- Організація предметного змісту дисципліни: відбір навчального матеріалу, дидактичне опрацювання його, побудова схем та таблиць для найкращого та наочного запам'ятовування.

- Вміння робити висновки та вміння аналізувати отриманні данні; інколи потрібно швидко проводити міжпредметні зв'язки для того, щоб аргументувати або пояснити свій результат з точки зору інших дисциплін.

Всьому цьому може навчити викладач під час професійної педагогічної діяльності виконуючи рефлексийні дії, але миттєво. Студенти починаючи спостерігати за його проведення занять поступово починають володіти рефлексивними діями.

Рефрлексія в педагогічній діяльності включає двох учасників - викладача та студента. Перша сторона педагогічної діяльності $€$ професійно важливою, викладач вміє осмислити внутрішній світ навчаючого, він здатний аналізувати свої дії в будь-яких ситуаціях, планувати свої дії, змінювати ситуацію педагогічного спілкування таким чином, щоб студенти отримували стимул до рішення проблеми. В свідомості викладача повинно бути особистість студента, його переживання, його дії.

Інша сторона рефлексій в педагогічній діяльності викладача відображення власного “Я” як суб'єкта професійної діяльності. Здатності викладача осмислювати свої дії, аналізувати, підходи до своїх дій з критичної точки зору. Профресійна рефлексія дозволяє викладачу зрозуміти не лише 
причини своїх дій, але як викладач досягає своєї мети.

Під час навчання завжди виникає взаємна рефлексія, а саме, між студентом та викладачем. В процесі такої взаємодії один із партнерів займає ведуче положення. Ведуче місце займає той хто здатний до великої мисленої взаємодії, а саме це є викладач. Такий тип партнерської взаємодії описується трьома складовими:

1) Перцептивна фоорма - це взаємосприйняття та розуміння один одного. Викладач повинен розмовляти доступною мовою для студентів, використовуючи студентський сленг та термінологію для кращого сприйняття;

2) Інтерактивна фоорма - пов'язана 3 емоційно-інтелектуальними взаємодіями викладач - студент під час суспільної діяльності. Як ми помітили, якщо викладач звертається до студентів "колеги" студенти починають активізувати свої розумові здібності;

3) Комунікативна форма. Вона характеризує передачу та сприйняття надходженної інфрормації під час навчального процесу. Саме комунікативна форма діяльності студента знаходиться в центрі навчального процесу.

Викладач, як учасник процесу навчання, повинен намагатися не лише задіяти свої комунікативні здатності, індивідуальні якості, а як активний суб'єкт рефлексії формувати та розвивати професіональну компетенцію, яка так необхідна для найкращого здійснення своєї професійної діяльності. Саме вміння викладача формулювати проміжкові та кінцеві цілі та задачі на кожному етапі навчання, вміння вибирати підходи, методи та форми навчання буде залежити від здатності до постійної рефлексії як викладача так і студента в подальшому.

Рефлексія для викладача, як нам здається, повинна бути інструментом утворення професіонального іміджу, формування ідей викладача. Найважливішим для викладача вищих навчальних медичних та фармацевтичних закладів $€$ вміння слухати студента, сприймати і розуміти його як особистість, а також одночасно осмислювати, як саме студент сприймає самого викладача. Це надає зворотній зв'язок в процесі навчання. Саме володіння інтроспективними, ретроспективними та перспективними видами рефлексії є показниками майстерності та творчості викладача. Всі ці види дозволяють зробити процес навчання більш творчим, також відбувається оцінювання моментів на зміни умов в навчанні. Необхідно пам'ятати навчання студентів рефлексивному, критичному мисленню, ґрунтується на власному досвіді і це дозволяє збудувати власну траєкторію професійного розвитку.

Тому в педагогічній практиці викладачі під час проведення заняття найчастіше використовують чорити компоненти:

- Цільовий компонент. Цей компонент включає в себе конкретну ціль, а саме формування у студентів хімічних компетенцій в процесі їх навчання. Викладач ставить ціль привити повагу та любов до свого предмету 3 подальшим самостійним вивчення цього предмету студентом. Для того, щоб запрацював цей компонент, потрібно вирішити задачі:

1) Викладач повинен забезпечити студента теоретичними знаннями о 
хімічній дисципліні;

2) Активізувати внутрішні пізнавальні мотивації до вивчення хімічної дисципліни;

3) Утворити умови для використання отриманих нових знань студентом при вивченні хімічних дисциплін, для розвитку фармацевтичних навичок.

Коли викладач здатний вирішити ці задачі, ми спостерігаємо зацікавленість предметом, намаганням студентом отримати нові знання. Також реалізація цілі будується на дидактичних, методологічних принципах 3 використанням компетентного, особисто-орієнтованого підходу. Всі ці моменти базуються на теоретико-методичній основі.

Компетентний підхід надає можливість виявляти вміння студента під час розв'язання проблеми. Саме в цьому підході студент виявляє свої здібності при розв'язанні професійних завдань. При особисто-орієнтоваому підході викладач намагається враховувати особистість студента, досвід самого студента $з$ хімічних дисциплін, підштовхнути до активний дій, а не просто відсидіти свій час.

Змістовий компонент він включає в себе систему хімічних знань, предметних навичок з дисципліни “Фізична та колоїдна хімія", "Неорганічна хімія", а саме під дією цих дисциплін формується хімічні компетентності. Головне завдання викладача під час професійної діяльності використовувати та виконувати три головні моменти, а саме:

- інформаційний блок - майбутні провізора повинні мати певні знання 3 даної дисципліни, а особливо спілкуватися використовуючи хімічну термінологію;

- мотиваційний блок - цей блок уявляє собою утворення позитивного та емоційного стану та атмосфери в групі, це дуже сприяє розумінню та рефлексивній роботі студентів;

- діяльнісний блок - відображає професійну діяльність студентів. Викладач під час проведення хімічних дисциплін пояснює моменти використання фрізико-хімічних методів в майбутній професії провізора.

Діяльнісний компонент в ньому відбувається самоосвітня робота студента. На другому курсі студенти вже мають певні хімічні навички та досвід, тому студент здатний отримувати хімічні знання, вміння та додаткові навички в процесі власної діяльності. Приймаючи участь в олімпіадах, конференціях. Всі ці моменти надають можливість формуванню хімічних компетенцій.

Результативно-оцінюючий компонент - надає можливість відслідкувати динаміку рівня сформованості хімічних компетенцій у студентів в медичних та фрармацевтичних вищих навчальних закладах. Оцінювання рівня сорормованості досліджується критеріями та показниками, які описують в програмах з певних дисциплін. Саме оцінювання надає можливість викладачу не лише оцінити студента, а ще виявити відхилення від цілі, яку ставив викладач та від коректувати шлях досягнення мети у студента. Тим самим допомогти вийти із трудного стану і взяти вірний шлях для отримання найкращого результату.

Висновки. Таким чином рефлективність це здатність, а сама рефлексія 
це механізм, який буде характеризувати рівень розвитку цієї здатності .

До основних компонентів рефлексивної культури можна віднести: рефлексивне середовище; рефлексивну компетентність; компетентність співтворчості; рефлексивно-інноваційний потенціал.

Для того щоб утворилося рефлексивне середовище викладач повинен вміти виходити за межі власного досвіду та вміти активізувати рефлексивноінноваційні процеси мислення через активізацію власних рефлексивних позицій. Тобто, основою педагогічної рефлексії $\epsilon$ особистісна рефлексія викладача, як деяка форма самопізнання, відношення до своєї педагогічної діяльності.

\section{Використана література:}

1. Безгина Ю. Б. Современные подходы к пониманию термина "Рефлексия". Альманах современной науки и образования. Тамбов: Грамота, 2007. № 1(1). С. 37-41.

2. Філіппова Л. В. Педагогічна рефлексія у вищій школі. Молодий вчений. 2019. № 2 (66). С. 132-136.

3. Хуторской А. В. Современная дидактика: ученик для вузов. Санкт-Петербург : Питер, 2001. 544 с.

4. Стеценко И. А. Теория и практика развития педагогической рефлексии студентов: монография. Ростов-на-Дону : Изд-во Ростов. гос.пед.ун-та, 2006. 256 с.

5. Основы профессионально-педагогической деятельности : учебное пособие для студентов среднего проф. образ. / Н. Н. Никитина, А. М. Железнякова, М. А. Петухов. Москва : Мастерство, 2002. $288 \mathrm{c}$.

6. Цукерман Г. А. Виды общения в обучении. Томск : Пеленг, 1992. 268 с.

7. Воронцов А. Б. Практика развивающего обучения по системе Д. Б. Эльконина, В. В. Давыдова. Москва: ЦПРО “Развитие личности”, 1998. 380 с.

\section{References:}

[1] Bezgina Iu. B. (2007). Sovremennye podkhody k ponimaniiu termina Refleksiia [Modern approaches to understanding the term "Reflection"]. Almanakh sovremennoi nauki i obrazovaniia. Tambov: Gramota, vol. 1(1), pp. 37-41.

[2] Filippova L. V. (2019). Pedagogicheskaya refleksiya v vysshiy shkole. [Pedagogical reflection in high school]. Molodoy vchenyy. № 2 (66), pp. 132-136.

[3] Khutorskoy A. V. (2001). Sovremennaya didaktika: uchenik dlya vuzov. [Modern didactics: a student for universities]. SPb: Piter, $544 \mathrm{p}$.

[3] Stetsenko I. A. (2006). Teoriya i praktika razvitiya pedagogicheskoy refleksii studentov: monografiya. [Theory and practice of the development of pedagogical reflection of students: a monograph]. Rostov-naDonu: Izd-vo Rostov. gos.ped.un-ta, $256 \mathrm{p}$.

[4] Nikitina N. N. (2002). Osnovy professional'no-pedagogicheskoy deyatel'nosti: Uchebnoye posobiye dlya studentov srednego prof. obraz. [Fundamentals of professional - pedagogical activity: a manual for students of secondary prof. Form]. Moskva: Masterstvo,. 288 p.

[5] Tsukerman G. A. (1992). Vidy obshcheniya v obuchenii.[Types of communication in training]. Tomsk: Peleng, $268 \mathrm{p}$.

[6] Vorontsov A. B. (1998). Praktika razvivayushchego obucheniya po sisteme D. B. Elkonina, V. V. Davydova. [The practice of developing training in the system of D. B. Elkonin, V. V. Davydova]. Moskva: TSPRO “Razvitiye lichnosti”, 380 p.

Филиппова Л. В. Профессиональная рефлексия преподавателя в высших учебных заведениях.

В статье рассматриваются подходы профессиональной рефлексии преподавателей, как самопознание, самоанализ. Описывается поэтапный прочесс самоанализа во время педагогического процесса и поэтапный прочесс самооченки, которые влияют на профессионально-личностное самосовершенствование преподавателя. Все главные этапы 
позволяют преподавателю распознать и познать внутренние процессы, которые происходят во время педагогической деятельности. Из педагогического уровня рефлексии раскрывается попытка преподавателя не только передать научно-практическую информацию студенту, но u попьтка преподавателя $\kappa$ саморазвитию рефлексівних собственных действий. Рассматривается влияние рефлексивної деятельности на познание собственной индивидуальности. Освещуаются четыре основных функичи, какие присущчие педагогической деятельности. Наблюдая студент за преподавателем, который под время практический занятий мгновенно используя основные функции, предоставляет яркий пример как можно завладеть рефлексивними действиями. Рассматривается партнерское взаимодействие преподавателя и студента с помощьью трех составных частей. Именно первая сторона педагогической деятельности занимает важное место во время педагогического процесса. Лишь преподаватель может вызывать мотивацию у студента для изучения и дальнейшего саморазвития своими действиями, используя определенные инструменть профессионального имиджа. Наводится описание всех компонентов, которыми пользуется преподаватель во время проведения практических или лекционных занятие. Происходит детальный анализ всех компонентов педагогической рефлексии, которые возникают во время обмена между преподавателем и студентом в педагогической деятельности преподавателя. B статье описывается попытка преподавателя научить студента критически мыслить на собственных действиях.

Ключевая слова: самопознание, самоанализ, целевой компонент, содержсательный компонент, діяльнісний компонент, результативно-оценивающиий компонент.

FYLYPPOVA L. V. Professional reflection of teachers in higher education institutions.

The article deals with the approaches of professional reflection of teachers, such as selfknowledge, introspection. The step-by-step process of introspection during the pedagogical process is described, as well as the step-by-step process of self-assessment, which influence the professional and personal self-improvement of the teacher. All the main stages allow the teacher to recognize and know the internal processes that occur during the pedagogical activity. From the pedagogical level of reflection, the teacher's efforts are revealed not only to convey scientific and practical information to the student, but also the teacher's efforts to self-develop reflexive actions. The influence of reflexive activity on the knowledge of one's own personality is considered. Four main functions that are inherent in pedagogical activity are highlighted. Watching a student lecturer, who instantly uses basic functions during a hands-on session, provides a vivid example of how reflexive actions can be mastered. The partnership between the teacher and the student is examined with the help of three components. The very first side of pedagogical activity occupies an important place during the pedagogical process. Only the teacher can motivate the student to study and further self-development through his / her actions, using certain tools of professional image. Provides a description of all the components that the teacher uses during the practical or lecture sessions. There is a detailed analysis of all components of pedagogical reflection that arise during the exchange between the teacher and the student in the pedagogical activity of the teacher. The article describes the teacher's efforts to teach the student to think critically in their own actions.

Keywords: self-knowledge, introspection, target component, content component, activity component, result-evaluating component. 